\title{
"A Watch Dropped in the Desert": Journey to a War and the New Life Movement
}

\begin{abstract}
By Qiang Zhang*
Through an analysis of the socio-ideological foundations of the New Life Movement in Republican China (1912-1949), this paper is a cross-cultural study of China's urban modernity in the 1940s with the example of Shanghai. It focuses on Journey to a War coauthored by W. H. Auden and Christopher Isherwood, which provides readers with counter-arguments that complicate this issue much more than Chiang Kai-shek's impulse of "romantic nationalism". The inquiry begins with the point observed by Auden that such a movement is not a modern problem; quite the contrary, it has solid roots in China's traditional culture. Through Auden's documentary review of the movement as the promise of social transformation under the Kuomintang leadership, the author argues that, generally speaking, Auden's critique of the failure of the movement is quite objective, but some points remain debatable. Through the Audenesque rhetoric in describing Chinese modernity as "A Watch Dropped in the Desert," the ambivalence of Chinese modernity is revealed through both dimensions of time and space in a global context. Thus, due to the unequal and simultaneous process of orientalization and occidentalization that alternately reminds readers of the combined ideologies adopted in the New Life Movement, Journey to a War provides us with a bystander's perspective in viewing the cultural and economic mechanism of the 1940s Chinese society.
\end{abstract}

\section{Introduction}

This paper intends to answer to what extent Auden and Isherwood's view is adaptable to the analysis of Chinese urban modernity, and what the New Life Movement means to a Western reporter that complicates our understanding of Chinese modernity in the global context. To answer those questions, the author historicizes the text Journey to a War in the overall socio-economic background of wartime China with supporting as well as opposing historical data from a cross-cultural perspective through the example of the capital market in Shanghai as an epitome of China's modernization. By contextualizing Shanghai in wartime China with historical documents as well as Auden and Isherwood's dramatic account in their Travel-Diary, the author generalizes their common concerns on the self-contradictory nature of the

"PhD Candidate, City University of Hong Kong, China. 
movement in guidelines and the scarcity of New Life spirits in economic activities. Both problematize New Life Movement as a modern response to the Chinese society.

In Journey to a War, co-authored by W. H. Auden (1907-1973) and Christopher Isherwood (1904-1986), there are elaborate descriptions of cities and villages during the New Life Movement that was inaugurated by Chiang Kai-shek on February $19^{\text {th }}, 1934$, when China, was already weakened by Western Imperialism, faced the threat of Japanese militarism, domestic factionalism and rising communism. In attempt to encounter these threats through the resurrection of traditional Chinese morality, Chiang in his speech "Gist of New Life Movement" delivered in Jiangxi, clearly summed up the essence of the campaign as a hygienic and behavioral reform by ways of education and politics. For sure, such top-down mandated political tactics through civic education were popular in many countries at the time, pretty much for the same purpose of national unification. Thus, it required social responsibility of intellectuals and participation of citizens, in Chiang's words, "thorough militarization." "

In the overall context of the Japanese invasion and the call for China's national salvation, the movement went far beyond a purge of the unhealthy habits of the Chinese people; rather, in Arif Dirlik's words, it was "a modern response to a modern problem." 2 By "modern response", Dirlik means that the measures taken by the national government were quite different from those taken by authorities in Chinese history, but they did not necessarily go against the spirit of Chinese tradition. Quite the contrary, "it would achieve the most fundamental goals of the Chinese revolution without sacrificing native tradition." James C. Thomson also regards this movement as a "hybrid composite of Confucian, fascist, Japanese, and Christian elements." "The hybridity of ideologies from various cultures might be considered as a modern response towards such social and ideological reform under the cloak of hygienic and behavioral specifications. However, both Dirlik and Thomson hold the idea that the so-called "modern response" failed to solve the "modern problem."

According to Western scholars who have commented on this movement, W. H. Auden took a view quite distinct from both Dirlik and Thomson in two ways: first, he believed that the combined thoughts advocated by the Nanjing National Government were official tactics more than a modern response;

\footnotetext{
${ }^{1}$ Kai-she Chiang, "Gist of New Life Movement," in Complete Works of Chiang Kai-shek, vol.12, ed. Qin Xiaoyi (Taipei: Zhongyang Wenwu Gongyingshe, 1983), 70.

${ }^{2}$ Arif Dirlik, "The Ideological Foundations of the New Life Movement: A Study in Counterrevolution," Journal of Asian Studies 34, no.4 (August 1975): 945.

${ }^{3}$ Ibid.

${ }^{4}$ James C. Jr. Thomson. While China Faces West: American Reformers in Nationalist China, 1928-1937 (Cambridge, Massachusetts: Harvard University Press, 1969), 152.

${ }^{5}$ Arif Dirlik, "The Ideological Foundations of the New Life Movement: A Study in Counterrevolution," Journal of Asian Studies 34, no.4 (August 1975): 945.

${ }^{6}$ Ibid.
} 
second, he contended in Journey to a War that the social problems the movement intended to solve were actually not modern at all.

There are two themes that run throughout Auden's travel writings: the reaction of Chinese society to the relentless Japanese intrusion and the implementation of the New Life Movement in people's lives. The former appeared in the foreword by Auden, saying that "the outbreak of the SinoJapanese War in August decided for us to go to China." However, Auden was not a representative of anything but the Random House that commissioned him to write a travel book about the East and of himself as a poet. The contrastive concepts of "East" and "West" do not only refer to geographical boundaries, but also, more importantly to cultural and ideological differences in crosscultural communications. Auden, together with Isherwood, met people from all walks of life, some of whom are acknowledged in the preface. In Auden's record of interviews or conversations with them, one frequent issue is that Chinese way of life needs improvement. Thus, he wrote down official as well as grass-root responses towards the movement, and further analyzed its inevitable failure due to the Chinese national characteristics, the economic base of China, and its inner motive to crumble the Communist Party. In this paper, I mainly focus on the first two points.

\section{The Lure of the City}

Most of the places Auden visited in China were significant cities in Republican China: Hong Kong, Guangzhou, Wuhan, Nanchang, Zhengzhou, Shanghai etc. By significant I mean their role in modern China's political, economic, and intellectual life. They are also the places where Auden obtained first-hand information. However, for Auden, the lure of cities does not only lie in the convenience of getting close to the central nerves of the policy-making system, but also in their modern lifestyles:

The clothing shops, the cafés, and the restaurants are kept by White Russian emigrants. You see two or three of them behind nearly every bar--- a fat, defeated tribe who lead a melancholy indoor life of gossip, mah-jongg, drink and bridge...

This is the real capital of war-time China. All kinds of people live in this town---Chiang Kai-shek, Agnes Smedley, Chou En-lai; generals, ambassadors, journalists, foreign native officers, soldiers of fortune, airman, missionaries, spies. $^{2}$

\footnotetext{
${ }^{1}$ W.H. Auden and Christopher Isherwood, Journey to a War. (London, Boston: Faber and Faber, 1973), 6. W. H. Auden and Christopher Isherwood left England in January 1938, and returned at the end of July.

${ }^{2}$ W.H. Auden and Christopher Isherwood, Journey to a War (London, Boston: Faber and Faber, 1973), 39-40.
} 
The above excerpt is only a brief description of wartime Hankou on $8^{\text {th }}$ of March, 1938. From Auden's words, we can find the lure of Hankou from at least three perspectives: first, elites from home and abroad gathered in this capital city. Their thoughts and social activities served as a signpost for China's future, in Auden's words, "to predict the events of the next fifty years." Second, the white Russian immigrants that had fled from the Russian October Revolution (1917) constituted part of the refugees who indulged the indoor life of entertainment as a temporary escape from reality. In that case, the lure of the city comes from its capability in giving people a comfortable and even luxurious life regardless of race and nationality. Third, the concessions in cities provided a platform for the exchange, clash and even integration of cultures. The community in Hankou in the 1940s, and perhaps many other cities in China as well, showed a certain degree of internationalization. Such so-called international concessions on the one hand isolated the foreign culture from the local, making it a city amid the city; moreover, they became sanctuaries for refugees during the Japanese invasion, like an oasis in the desert. The charm of those cities also resided in the possibility of cross-cultural interactions whether it was a spontaneous or mandatory process in wartime China.

The huge gap between the high quality of life that a modern city had promised and its dilapidated infrastructure certainly manifests the necessity of a hygienic movement. From Auden's depiction of Shanghai as a city "Nowhere a fine avenue, a spacious park, an imposing central square. Nowhere anything civic at all,"2 we could perceive his antipathy to Shanghai, which was deified as the symbol of Chinese urban modernity. Therefore, Chiang's movement seemed to be effective in solving the hygiene problems through military means.

[T]he fundamental way of bringing about the nation's recovery lies in the improvement of the daily life of the people. In the matter of clothing, food, and housing, the people must cultivate the habit of the order, cleanliness, simplicity and frugality. Furthermore, the people must respect the qualities of a gentleman, as they were taught many centuries ago by Confucius, which include: "Li, Yi, Lien, Chih." These four characters stand for:" Good manners, chivalry, honesty and consciousness." The last-named quality is a little difficult to define. It means that a person should be conscious of his own disgrace and should by every means remove it. ${ }^{3}$

From the guiding spirit of the movement, we could see its combined influence of Confucianism and gentlemen culture that share a common moral standard of Li Yi Lien Chih. This concept originates from "On Governing the People," a classical Chinese treatise, in explaining the four dimensions of

\footnotetext{
${ }^{1}$ Ibid., 40.

${ }^{2}$ Ibid., 237.

3“'Country Turns to New Life: Movement Sponsored by Gen. Chiang Kai-shek." North China Herald, Mar. 21, 1934.
} 
governing a country, " $L i$ means people should not go beyond the norms they follow; with $Y i$, people will not behave rashly; with Lien, they will not cover their mistakes; with Chih, they will not succumb to the evil." "Sun Yat-sen developed such an idea in interpreting his Sanmin zhuyi "Three Principles of the People." Chiang's re-interpretation did not deviate from Guanzi's doctrine, but quite the contrary, used local heritage as a way to interfere with the life of citizens. Thus, the emphasis on these virtues as a nationwide movement was the application of traditional Chinese learning in a new historical and ideological context, especially in a historical moment when nationalism permeated Chiang's speech. To a great extent, in the cultural context China in the 1940s, ideas imported from the West were usually regarded by Chinese intellectuals as "new."

The call for virtues is also prevalent in Auden's poetry; that is to say, as a poet who experienced two world wars, he was discontented with the lack of morality and ethics in the world. In retrospect, of two other catastrophes in human history, the fall of the Roman Empire and the decline of Christianity, he listed the Second World War as the third one because it fully exposed the darkness of human nature. Moreover, the city, as the center of human civilization, was alienated as the stage for the manifestation of human evils. Thus, in Auden's poems, cities have lost their vitality but are infused with the atmosphere of death and horror. Such negative images can be found in many of his poems in depiction of wartime cities both East and West.

In Auden's China sonnets, cities in most cases are haunted with the shadow of war and desperation, "Think in this year what pleased the dancers best,/ When Austria died, when China was forsaken,/ Shanghai in flames and Teruel re-taken."2 That relates to Auden's as well as many intellectuals' doubt at his time--- whether such movement advocated by Chiang based on hygienic and behavioral reform could really achieve its goal without national independence, or even, whether it is an untimely campaign that is irrelevant to solving the principal contradiction in Chinese society.

To answer that question, Auden made his social analysis from a panoramic view in his Journey to a War, including motivation of the ruling class, national beliefs and tradition, and social and economic infrastructure.

\section{The Fall of the New Life Movement}

Although some critics take Auden's Journey to a War and China Sonnets as documentaries in recounting the Sino-Japanese war, Marsha Bryant doubts that Auden and Isherwood faces "not only the problem of meeting their readers' expectations but also the challenge of validating their status as

\footnotetext{
${ }^{1}$ Guan Zhong (Guan Zi), "On Governing the People," in Notes and Interpretations on Guanzi, ed. Zhao Shouzheng (Nanning: Guangxi Renmin Chubanshe, 1982), 1.

${ }^{2}$ W. H. Auden, Collected Poems, ed. Edward Mendelson (New York: Vintage books, 1976), 193.
} 
documentary men." Indeed, images of their expeditions recorded in Journey to $a$ War did not show their lack of contact with the frontline and instead showed their intimacy with the local upper class and embassy officials.

In Journey to a War, Auden and Isherwood occasionally wrenched themselves from the dichotomized framework and saw the suffering of the Chinese people. The most obvious example occurs when they showed sympathy for the suffering of the people under the invasion of the Japanese army and the expansion of the Western economy. The juxtaposition of such double elements is reflected in Auden's photograph "Japanese Sentry," in which the visual incongruity is presented with a Japanese soldier with a rigid facial expression and a "Watson's" billboard as a background. However, that does not mean they are totally irrelevant, but rather, are two powers that haunted wartime China, the Japanese military power and the British economic power. Marsha Bryant even claims that "the photograph questions the authors'-- and their country's--- claim to side with China in this war."2 Indeed, Auden's imperial vision would inevitably oscillate between his Euro-centrism and pacifism. The distance between them is not unbridgeable, but is connected by those two power relations, and also, it was such power-politics and powereconomics that motivated the New Life Movement. In Lloyd Eastman's words, "it is to thoroughly militarize the lives of the citizens...so that they will cultivate...the endurance of suffering and tolerance for hard work...so that they will at any time sacrifice for the nation." 3 The role of politics permeated almost all spheres of social life, economy included; that's why Carlton Benson argued that "consumers are also soldiers" in this campaign.

In this part, I focus on Auden and Isherwood's view on the inherent mode of production in the Chinese society, and its adaptation in urban modernity with Shanghai as an example. In that way, I intend to elaborate the contradiction that how a consumer culture invigorated and deteriorated the movement.

The transformation from the traditional economic model to the pattern of a capital market is an important aspect of Chinese modernity, and also, it is what the New Life Movement aims to achieve in the national economy. That's why among the twelve policy objectives enacted by the Generalissimo on behalf of the People's Economic Reconstruction Movement, terms like "modern lines" and "modern practice" seem to show the advanced nature of the campaign, and certainly call for a new mode of production relations.

\footnotetext{
${ }^{1}$ Marsha Bryant, Auden and Documentary in the 1930s (Charlottesville and London: University Press of Virginia, 1997),136.

${ }^{2}$ Ibid., 161.

${ }^{3}$ Lloyd Eastman, The Abortive Revolution: China Under Nationalist Rule, 1927-1937 (Cambridge and London: Harvard University Press, 1974), 68.

${ }^{4}$ Carlton Benson, "Consumers Are Also Soldiers: Subversive Songs from Nanjing Road During the New Life Movement," in Inventing Nanjing Road: Commercial Culture in Shanghai, 19001945, ed. Sherman Cochran (Ithaca, NY: Cornell University, 1999), 91.

${ }^{5}$ C. W. H. Young, New Life for Kiangsi, (Shanghai: The China Publishing Cooperation, 1935), 162.
} 
McClure (in the Travel-Diary), a Canadian Scot who ran his own hospital at Wei-hwei before it fell into the hands of the Japanese army, saw the deficiency of the traditional Chinese peasant economy and believed it to be the major hindrance in economic modernity, because it corrupted two basic requirements of the modern economic model, cooperation and honesty. For a traditional agricultural society, those pernicious habits also permeated industrial production. Thus, drawing on the accepted duty to promote a modern and industrialized nation, Chiang was also aware of the importance of intellectual improvement as a "simultaneous action....a thoroughgoing scheme for the education of the illiterate and old-fashioned people." Although the Generalissimo did not define what he meant by "old-fashioned," he did mention clearly what should be removed from this movement, namely "superstitious ideas as well as conservative notions born of ignorance." 2 The lack of business ethics also has inextricable relationships with the uneven distribution of the capital, the different demands of classes, and also, the practical needs of wartime China. In that case, there are at least three pairs of paradoxes making the slogans of the campaign nonsense:

The first and foremost contradiction is between the luxury in material consumption and the poverty of civil society caused by the unbalanced distribution of the capital during city construction. Interestingly, a cosmopolitan life style with modern taste and a life of simplicity and frugality were both advocated by the authority. Shanghai, as a metropolis in East Asia, was almost no different to Western cities in terms of cultural and sensual enjoyment in Auden and Isherwood's Travel-Diary.

Without context, Auden's description of Shanghai in his Travel-Diary could be an epitome of all large cities in his contemporary time, either East or West. People enjoyed a cozy and even luxurious life, showing the lure of the modern. The consumer culture in Shanghai in the 1930s was not local or national, but international, or maybe even cosmopolitan, showing the inevitable trend of modernity. However, the term modernity to Auden does not only relate to fantasy for the future, but also to a vision of history, how "the ancient discontents survived in contemporary forms." 3 That is where Auden's sense of public responsibility lies, because he began to warn his audience instead of eluding discontents from the working class that was silenced by the bustling prosperity. However, there was a certain undercurrent of disharmony on the allocation of the capital embodied by the ghettoized economic zone divided by concessions. $^{4}$

\footnotetext{
${ }^{1}$ Ibid.

${ }^{2}$ Ibid.

${ }^{3}$ Edward Mendelson, "Auden's Revision of Modernism," in Modern Critical Views: W. H. Auden, ed. Harold Bloom (New York: Chelsea House Publishers, 1986), 111.

${ }^{4}$ See W. H. Auden, Journey to a War (London and Boston: Faber and Faber, 1973), 230. "The International Settlement and the French Concession form an island, an oasis in the midst of the stark, frightful wilderness which was once the Chinese city. Your car crosses the Soochow Greek: on the one side are streets and houses, swarming with life; on the other is a cratered and barren moon-landscape, intersected by empty, clean-swept roads."
} 
The distinct landscape on both sides of the Suzhou River demonstrated uneven distribution of the capital that coincided with geographical boundaries. On the one hand, we have to admit the importance of the materials in the construction of urban civilization. In 1932, Kodak Travels commented that "Shanghai gained her special position on the basis of material prosperity in construction, transportation, and life." The problem occurred at the same time in that Auden's characters immersed in urban prosperity are often consumers and collectors of social wealth rather than producers or creators of material wealth. The Economic Repository in 1939 criticized the phenomenon that the untimely growth of the consumption of luxury was not effectively controlled by the authority, and the discussion of consumers in most cases referred only to "the wealthy class," because for those who suffered from war and unemployment, "even the consumption of daily necessities is a problem." 3

However, the living conditions of the workers and industrial production in the New Life Movement were ignored by the government. Safety of workers was not protected by the law. Quality of life as an alternative lifestyle to them was no more than a mirage. Mr. Rewi Alley, a factory inspector and official of the Public Works Department in Shanghai, noticed the production of surplus values through inhumane means, such as the symptoms of lead poisoning amongst child labor in a battery factory, fungal infections caused by steam in filatures, tuberculosis resulting from cotton dust, and child abuse in factories. Rewi Alley criticized that "Accidents are invariably found to be due to the carelessness of the workers involved. There is no compensation and no insurance." ${ }^{4}$ The workers suffered not only from a minimum protection of personal health, but also, the high risk of unemployment. Because of the war, the destruction of plants created tremendous supplies of surplus labor. In the Travel-Diary, Isherwood took the example of silk factories, saying that "women's wages have fallen from thirty to twenty cents a day." Statistics from the International Labour Bulletin (1939) ${ }^{6}$ shows that within the filature industry in Shanghai, the average salary of female labor declined from $\$ 16.345$ in the year 1937 to $\$ 6.766$ in 1938; however, the average working hours per day extended from 10 to 11.19. In Alley's opinion, workers suffered exploitation not only from their Chinese owners, but from the Japanese more brutally.

In Chiang's address in 1934, he said "The poverty of our nation is primarily caused by the fact that there are too many consumers and too few producers. To remedy this we have to emphasize the four virtues, and we have to make people work harder and spend less.... It is also the primary cause of

\footnotetext{
1،'Image of Waitan," Kodak Travel 3, no.11 (1931): 7.

${ }^{2}$ Ibid., 25.

${ }^{3}$ Ibid.

${ }^{4}$ W.H. Auden and Christopher Isherwood, Journey to a War (London, Boston: Faber and Faber, 1973), 236.

${ }^{5}$ Ibid.

"'Statistics on Workers' Salaries and Working Hours from 1937 to 1938," International Labour Bulletin 6, no.3 (1939): 42.
} 
the strength of modern nations."1 Chiang's paramount aim, of course, was to create a strong nation state through a so-called people's movement with the government taking the actual leading role. That concludes to the paradox of its economic prospect: the discrepancy between the wishful remolding of personal habits and the neglect of conditions that caused poverty, dishonesty, corruption and market downturn. Therefore, moralistic remedies advocated by the authority were far from enough to solve the economic problems.

However, all five reasons that brought about inflation in Shanghai elaborated by the Economic Repository in 1939 were related to urgent needs of wartime China. The war blocked contacts between Shanghai and its suppliers of material goods, causing the rushing floods of refugees to concessions, resulting in the increase of production costs. In addition, natural resources were in the hands of consortiums or foreign forces; and costs of materials were heavily influenced by the foreign exchange market. ${ }^{2}$

The Travel-Diary records a survey conducted by the hospital authorities in Shanghai amongst patients to discover their reasons for joining the army. The result shows that 85 out of 142 respondents believed economic reasons and family difficulties were their primary concern, while 23 of them attributed to patriotism as their initial motivation; ${ }^{3}$ nevertheless, economic difficulties in turn were the consequence of colonization and Shanghai's role as an economic base for the Japanese war machine remained unchanged. Auden and Isherwood observed that "Of the 130,000 operatives now employed in Shanghai ninety percent are working for the Japanese," not only because they occupied resources like canals, railways, cotton and silk mills, but also, more importantly, factories in international zone could only consolidate Shanghai's role as the economic support for Japan's military and political strategies. Auden saw the paradoxical relationship within imperialism and all forms of exploitation as such,

[A]ll forms of exploitation, is possible for a time only because the exploited need the exploiters, that is to say, there is a real basis for love between them. It is unworkable in the long run because it fails to satisfy the needs, not of the exploited but of the exploiters. ${ }^{5}$

Auden believed that imperialism, colonialism and all forms of exploitations violate the laws of economy, in his own words, "It's impossible to receive without giving." 6 The violation of equality in commerce would eventually lead to the development of the agricultural and industrial cooperative movement in direct rivalry to the assault of foreign commodity

\footnotetext{
${ }^{1}$ Chiang Kai-she, Outline of the New Life Movement, trans. Mme. Chiang (Nanchang: Association for the Promotion of New Life Movement, 1930), 10.

${ }^{2 ، " F r o m ~ L u x u r y ~ L i f e ~ i n ~ S h a n g h a i ~ t o ~ S o a r i n g ~ P r i c e s, " ~ E c o n o m i c ~ R e p o s i t o r y ~} 1$ (1939): 25.

${ }^{3}$ W. H. Auden and Christopher Isherwood, Journey to a War (London, Boston: Faber and Faber, 1973), 239.

${ }^{4}$ Ibid.

${ }^{5}$ W. H. Auden, The Prolific and the Devourer (NJ: The Ecco Press, 1976), 64.

${ }^{6}$ Ibid.
} 
markets. The co-operative movement and New Life Movement complemented each other, revealing that the hygienic and behavioral campaign under the guidance of the four virtues as the unifying ideology was powerless to solve national crisis.

\section{The Watch Continues}

In the conclusion of the Travel-Diary, Auden and Isherwood described China's situation in a grotesque but structuralized manner.

In this city (Shanghai) --- conquered, yet unoccupied by its conquerors--- the mechanism of the old life is still ticking, but seems doomed to stop, like a watch dropped in the desert. In this city the gulf between society's two halves is too grossly wide for any bridge. There can be no compromise here. And we ourselves, though we wear out our shoes walking the slums, though we take notes, though we are genuinely shocked and indignant, belong, unescapably, to the other world. We return, always, to Number One House for lunch. ${ }^{1}$

Using "watch" and "desert" as metaphorical image of time and space is typical of Audenesque rhetoric, which "promotes the fusing of ideas and enables antithetical emotions to illuminate each other." 2 The ambivalence of Shanghai, or Chinese cities in general that are recorded in the Travel-Diary is mainly embodied in Auden's conception of time and space. The fusion of time occurs when Auden saw the irreconcilable contradictions between an old life as heritage of ancient Chinese civilization and a modern lifestyle flaunted by the Western world. Auden's point is quite clear, that the mechanism of the old life is doomed to stop because it lost impetus in promoting a competitive economic, political and even military force for the nation state. That is based on the logic of social Darwinism, the survival of the fittest, simply for the reason that all lifestyle has to keep pace with time. In Auden's words, "O let not Time deceive you,/ You cannot conquer Time."3

The word "Time" in "The Capital" shows its irreplaceable and unconquerable power in a unidirectional movement, a journey with no traveler return. Therefore, watch as the machine that measures time is endowed with symbolic meaning and is also the product of industrial machinery. Perhaps it is for that reason that "time" is alienated into a hostile image in "Lay Your

\footnotetext{
${ }^{1}$ W. H. Auden and Christopher Isherwood, Journey to a War (London, Boston: Faber and Faber, 1973), 242.

${ }^{2}$ Peter Porter, "Auden's English: Language and Style," in The Cambridge Companion to W. H. Auden, ed. Stan Smith (Cambridge: Cambridge University Press, 2004), 135.

${ }^{3}$ W. H. Auden, Collected Poems, ed. Edward Mendelson (New York: Vintage books, 1976), 134.
} 
Sleeping Head," where "Time and fevers burn away/ Individual beauty from/ Thoughtful children."

Spatial dimension also constitutes Auden's perception of modern cities in terms of binary confrontation between East and West. Although Auden and Isherwood travelled to many cities, towns, as well as war fronts, they declare that they still "belong, unescapably, to the other world." refers to the Western one, seeing the Oriental culture as the Other. ${ }^{3}$

Their view reinforced the ideological confrontation between the two worlds and overemphasizes the cultural incommensurability that hinders the cross-cultural communication. In their opinion, the discussion of the New Life Movement as a mass campaign in promoting Chinese modernity was still under the overall discourse of cultural hegemony, with the premise of a univocal modernity as the norm for other worlds, which harshly negates the possibility of its variants. In that way, Chinese urban modernity was only a replica of the original, an imaginary existence that owns the right to judge. Therefore, the British would agree in describing "the only decent Japanese", as the mere positive image of the orient based on the fact that they best followed the Western model. Stuart Christie argues that "China serves mainly as an occult imagining against which the poet attempts to locate his increasingly liminal position in nationalist British culture and letters." ${ }^{, 5}$ Thus, it is reasonable to doubt if Auden's Sonnets from China and Journey to a War really come from China at all due to the unequal and simultaneous process of orientalization and occidentalization that alternately reminds readers of a cultural center.

\section{Conclusion}

The Oriental perceptions of wartime China in Journey to a War coincide with Auden's contemporary imperialist vision on seeking the European shadow of cities in the East. At the same time, they both saw the oriental civilization as a riddle, a mystery that was yet to be re-discovered, which catered to the tastes of their target readers as indicated in the travel diary, Westerners who know little of China. Their interpretive framework is explicitly revealed in the language style in recording the anecdotes they encountered, but that does not mean they see China differently, because the absurdities and helplessness they

\footnotetext{
${ }^{1}$ W. H. Auden, Selected Poems, ed. Edward Mendelson (New York: Vintage Books, 1979), 50.

${ }^{2}$ W. H. Auden and Christopher Isherwood, Journey to a War (London, Boston: Faber and Faber, 1973), 242.

${ }^{3}$ See W. H. Auden and Christopher Isherwood, Journey to a War (London, Boston: Faber and Faber, 1973), 246. "In our world, there are the garden-parties and the night-clubs, the hot baths and the cocktails, the singsong girls and the Ambassador's cook. In our world, European business men write to the local newspaper, complaining that the Chinese are cruel to pigs, and saying that the refugees should be turned out of the Settlement because they are beginning to smell."

${ }^{4}$ Ibid.

${ }^{5}$ Stuart Christie, "Disorientations: Canon without Context in Auden's 'Sonnets from China,"” PMLA 120, no.5 (2005): 1577.
} 
witnessed during the New Life Movement did show the deficiencies of this government-mandated top-down mass campaign, far from the actual needs of wartime China.

Auden and Isherwood, as foreign journalists, analyzed the fall of the movement through ideological, cultural, historical, and economic perspectives. Their acute criticisms on the intrinsic motivation of the campaign, the pragmatic ideology as national character, and the trouble of the capital market in Shanghai are based on fair historical data.

Using Shanghai as an example, Auden realized the sharp opposition between the booming modern large-scale mechanical production and decadence of human nature, which is not a special case for China. Situating the dilemma of Chinese modernity in the global context in a metaphorical manner, Auden provided us with a new perspective to evaluate the legacy of New Life Movement.

\section{Bibliography}

Auden, W. H. Collected Poems, Edited by Edward Mendelson. New York: Vintage books, 1976.

Auden, W. H. The Prolific and the Devourer. NJ: The Ecco Press, 1976.

Auden, W. H. and Christopher Isherwood. Journey to a War. London, Boston: Faber and Faber, 1973.

Auden, W. H. Selected Poems, Edited by Edward Mendelson. New York: Vintage Books, 1979.

Benson, Carlton. "Consumers Are Also Soldiers: Subversive Songs from Nanjing Road During the New Life Movement." In Inventing Nanjing Road: Commercial Culture in Shanghai, 1900-1945, edited by Sherman Cochran, 91-132. Ithaca, NY: Cornell University, 1999.

Bryant, Marsha. Auden and Documentary in the 1930s. Charlottesville and London: University Press of Virginia, 1997.

Chiang, Kai-she. "Gist of New Life Movement." In Complete Works of Chiang Kaishek, vol.12, edited by Qin Xiaoyi, 70-80. Taipei: Zhongyang Wenwu Gongyingshe, 1983.

Chiang, Kai-she. Outline of the New Life Movement. Translated by Mme. Chiang. Nanchang: Association for the Promotion of New Life Movement, 1930.

"Country Turns to New Life: Movement Sponsored by Gen. Chiang Kai-shek." North China Herald, Mar. 21, 1934.

Dirlik, Arif. "The Ideological Foundations of the New Life Movement: A Study in Counterrevolution." Journal of Asian Studies 34, no.4 (August 1975): 945-980.

Eastman, Lloyd. The Abortive Revolution: China Under Nationalist Rule, 1927-1937. Cambridge and London: Harvard University Press, 1974.

"From Luxury Life in Shanghai to Soaring Prices." Economic Repository 1 (1939): 25.

Guan, Zhong (Guan Zi). "On Governing the People." In Notes and Interpretations on Guanzi, Edited by Zhao Shouzheng. Nanning: Guangxi Renmin Chubanshe, 1982.

"Image of Waitan.” Kodak Travel 3, no.11 (1931): 7. 
Mendelson, Edward. "Auden's Revision of Modernism." In Modern Critical Views: W. H. Auden, edited by Harold Bloom. New York: Chelsea House Publishers, 1986.

Stuart, Christie. "Disorientations: Canon without Context in Auden's 'Sonnets from China." PMLA 120, no.5 (2005): 1576-1587.

Porter, Peter. "Auden's English: Language and Style.” In The Cambridge Companion to W. H. Auden, edited by Stan Smith. Cambridge: Cambridge University Press, 2004.

"Statistics on Workers' Salaries and Working Hours from 1937 to 1938." International Labour Bulletin 6, no.3 (1939): 42.

Thomson, James C. Jr. While China Faces West: American Reformers in Nationalist China, 1928-1937. Cambridge, Massachusetts: Harvard University Press, 1969.

Young, C. W. H. New Life for Kiangsi. Shanghai: The China Publishing Cooperation, 1935. 
